\title{
Synthesis, in vitro biological evaluation and molecular modelling of new 2-chloro-3-hydrazinopyrazine derivatives as potent acetylcholinesterase inhibitorś| on $\mathrm{PC} 12$ cells
}

Maryam Taheri ${ }^{1}$, Samira Aslani ${ }^{1}$, Hossein Ghafouri ${ }^{12^{*}}$, Asadollah Mohammadi ${ }^{3}$, Vaha Akbary Moghaddam', Nastarn Moradi ${ }^{1}$ and Hananeh Naeimi ${ }^{1}$

\begin{abstract}
Background: The loss of cholinergic neurotransmission in Alzheimer's disease (AD) patients' brain is accompanied by a reduced concentration of Acetylcholine (ACh) within synaptic clefts. Thus, the use of acetylcholinesterase inhibitors (AChEls) to block the cholinergic degradation of ACh is a promising approach for AD treatment. In the present study, a series of 2-chloro-3-hydrazinopyrazine derivatives (CHP1-5) were designed, synthesized, and biologically evaluated as potential multifunctional anti-AD agents.

Methods: In addition, the chemical structures and purity of the synthesized compounds were elucidated through using IR, ${ }^{1} \mathrm{H}$ and ${ }^{13} \mathrm{C}$ NMR, and elemental analyses. Further, the intended compounds were assessed in vitro for their AChE inhibitory and neuroprotective effects. Furthermore, DPPH, FRAP and ABTS assays were utilized to determine their antioxidant activity. The statistical analysis was performed using one-way ANOVA.

Results: Based on the results, CHP4 and CHP5 exhibited strong AChE inhibitory effects with the $\mathrm{IC}_{50}$ values of 3.76 and $4.2 \mu \mathrm{M}$ compared to the donepezil $(0.53 \mu \mathrm{M})$, respectively. The study examined the effect and molecular mechanism of CHP4 on the Ab1-42-induced cytotoxicity in differentiated PC12 cells. At concentrations of 0-100 $\mu \mathrm{M}, \mathrm{CHP} 4$ was non-toxic in PC12. Additionally, Ab1-42 significantly stimulated tau hyperphosphorylation and induced differentiated PC12 cell death. Further, CHP4 resulted in diminishing the Ab1-42-induced toxicity in PC12 cell significantly. CHP4 at $30 \mu \mathrm{M}$ concentration significantly increased the Ab1-42-induced HSP70 expression and decreased tau hyperphosphorylation.
\end{abstract}

Conclusions: According to the results of our studies CHP4 can be considered as safe and efficient AChEl and employed as a potential multifunctional anti-AD agent.

Keywords: Acetylcholinesterase inhibitors, Alzheimer's disease, 2-Chloro-3-hydrazinopyrazine, PC12 cells

*Correspondence: h.ghafoori@guilan.ac.ir

1 Department of Biology, Faculty of Basic Sciences, University of Guilan, Rasht, Iran

Full list of author information is available at the end of the article

\section{Background}

$\mathrm{AD}$ is considered as one of the most causes of dementia and neurodegenerative disease among senile individuals, which may occur in $60 \%$ of cases. About 50 million individuals have dementia worldwide, to which 
approximately 10 million new cases are added every year. The total number of dementia individuals is expected to reach 82 and 152 million in 2030 and 2050, respectively $[1,2]$. AD is characterized by the aggravation of cognition, function, and behavior, as well as losing memory. The growth of amyloid- $\beta$ (A $\beta$ ) peptide deposits and hyperphosphorylated tau protein (Tau-p) in brain tissue has been addressed as the most important pathological hallmarks with AD [3]. In addition, heat shock proteins (HSPs) are an important class of molecular chaperones, which can involve under stress conditions such as hypoxia, oxidative stress, proteotoxic stress, inflammation, and several diseases like cancer, $\mathrm{AD}$, and other neurodegenerative diseases. AD is associated with a type disorder of protein accumulation [4-6]. Further, HSP70 activation stabilizes Tau-p both in neuronal cells and brain tissues in the neurodegenerative diseases such as AD, Parkinson's disease (PD), and epilepsy. HSP70 proteins are up-regulated in response to stress although it's up-regulation can be damaging because of worsening the chronic inflammation [7-10].

Oxidative stress is detected as one of the causing factors in aging, which contributes to the development of multiple neurodegenerative disease such as $\mathrm{AD}$, and plays an important role in destroying neuronal cells. Therefore, this process is considered as one of the primary incidents in AD. Accordingly, the effective protection of neuronal cells against oxidative stress damage can potentially prevent $\mathrm{AD}$ [11]. In $\mathrm{AD}$, inflammatory processes generate reactive oxygen species (ROSs) leading to the dysfunction of antioxidant system [12]. AD is related to a decrease in ACh level in hippocampus (a part of medial temporal lobe memory system) and neocortex, especially in frontal and temporal lobes by cholinergic system deficiency such as the death or atrophy of basal forebrain cholinergic neurons [13]. Furthermore, the reduction of Ach synaptic availability is caused by basal forebrain cholinergic loss and memory deficits in AD [14]. Cholinesterases (ChEs) catalyze Ach hydrolysis into choline and acetate, which is an essential process in the cholinergic neurotransmission. Two types of ChEs are available, AChE (EC3.1.1.7) and Butyrylcholinesterase (BuChE, EC3.1.1.8), the first of which is one of the important factors in $\mathrm{AD}[15,16]$. AChE is involved in the termination of impulse transmission by hydrolyzing $\mathrm{ACh}$ in numerous cholinergic pathways in the nervous systems. Indeed, the active site of AChE is placed in the bottom of the molecule and contains anionic and esteratic subsites, and catalytic machinery and choline-binding pocket are related to esteratic and anionic subsites, respectively [17]. The catalytic machinery site is placed at the middle of the gorge and involves the catalytic triad (H447, E334, and S203) in human AChE. Further, the anionic site is formed by the side chains of Glu202, Trp86, and Tyr337, and considered as responsible for binding the ACh [18]. Some drugs such as tacrine, rivastigmine, donepezil, and galantamine have been consumed for years in most countries to diminish AD symptoms, which inhibit AChE. However, the number of $\mathrm{AD}$ patients is increasing and no definite treatment is currently available in this regard. There are many synthetic and natural inhibitors of AChE [19]. Furthermore, novel AChEIs have been designed and produced from a series of some 3,5-dimethoxy- $\mathrm{N}$-methylenebenzenamine and 4-(methyleneamino) benzoic acid derivatives comprising of $N$-methylenebenzenamine nucleus (imin-metal) [20]. Pyrazine is one of the main types of heterocyclic compounds, synthesized chemically or extracted from natural sources [21]. So far, several synthesized derivatives of pyrazine have been introduced as important drugs and 2,5-dichloropyrazine is a basic starting compound for preparing many bioactive pyrazines $[22,23]$. Pyrazine ring has become important in representing diverse biological activities in interaction with other scaffolds such as pyrrole, pyrazole, thiophene, oxazole, pyridine, triazole, tetrazole, imidazole, piperidine, and piperazine [24]. The presence of pyrazine ring as a vital scaffold in different clinically-used drugs exhibits its importance in drug design. Considering the above-mentioned reports, the present study sought to design and synthesize several novel 2-chloro-3-hydrazinopyrazine derivatives (CHP1-5) based on their pyrazine and formyl for assessing their inhibitory effects on the AChE in order to obtain new ligands with efficacy and high inhibitory effect. Then, the other biological evaluations such as antioxidant activity, enzyme, and cell protective assays were performed. The results suggested $\mathrm{CHP} 4$ as an effective AChEI. Among all compounds under study, CHP4 represented the highest antioxidant properties. Based on the results of anti-Alzheimer's studies and molecular docking ones on this compound, the protective effect of CHP4 against the $\mathrm{A} \beta$-induced damage in $\mathrm{PC} 12$ cells was caused by changing Tau-p expression. In addition, the roles of HSP70 in the protective effect of CHP4 were considered in the present study. Finally, the results may propose the usage potential of CHP4 in subsequent research on AD.

\section{Methods}

Chemistry

Chemical materials, 2-chloro-3-hydrazinopyrazine; chromene; methoxy benzaldehyde; 3-hydroxybenzaldehyde; 2-hydroxybenzaldehyde; 4-chlorobenzaldehyde; glacial acetic acid and TLC-RP 18 (Silica gel 60) were purchased from Sigma-Aldrich. 


\section{Synthesis of the pyrazine-based Schiff-bases (CHP1-CHP5)}

The 2-chloro-3-hydrazinopyrazine and formyl derivatives utilized to synthesize Schiff-bases and other chemicals were obtained from Sigma-Aldrich and Merck. Additionally, double-distilled water was consumed throughout the experiment and $n$-hexane-ethyl acetate solvent system was used as an eluent. Thin layer chromatography (TLC Silica gel 60 F254, Merck) was employed for determining the substrate purity and monitoring reaction. Further, an electrothermal melting point device was applied for specifying all melting points (mp). The visible spectra and FTIR ones in $\mathrm{KBr}$ pellets were respectively measured on a Pharmacia Biotech spectrophotometer and a Shimadzu 8400 FT-IR spectrophotometer. Furthermore, a FT-NMR (400 MHz) Brucker apparatus was used for recording ${ }^{1} \mathrm{H}$ and ${ }^{13} \mathrm{C}$ NMR spectra. Chemical shifts were expressed in $\delta$ ppm using TMS as an internal standard and coupling constants $(J)$ were given in $\mathrm{Hz}$.

The pyrazine-based Schiff-bases were prepared through the condensation reaction of 2-chloro-3-hydrazinopyrazine $(0.5 \mathrm{mmol})$ with various formyl derivatives $(0.5 \mathrm{mmol})$ in ethanol $(15 \mathrm{~mL})$ in high yield. As a typical procedure, $0.5 \mathrm{mmol} 2$-chloro-3-hydrazinopyrazine was added to a mixture of a formyl derivative $(0.5 \mathrm{mmol})$, absolute ethanol $(15 \mathrm{~mL})$, and glacial acetic acid (organic catalyst) in a $50-\mathrm{mL}$ round-bottom flask and heated to reflux with stirring for $7 \mathrm{~h}$. The reaction progress was monitored through TLC using n-hexane: ethyl acetate (6:4) as solvent. After completing the reaction, the reaction mixture was cooled to room temperature, and the precipitate was collected by using vacuum filtration and washed with deionized water several times for affording the pyrazine-based Schiffbases. Then, the products were isolated through recrystallization from $\mathrm{DMF} / \mathrm{H}_{2} \mathrm{O}$. Finally, the structure of the obtained Schiff-bases was confirmed by using FT-IR and ${ }^{1} \mathrm{H}$ and ${ }^{13} \mathrm{C}$ NMR spectroscopy.

\section{(E)-2-chloro-3-(2-(4-methoxybenzylidene) hydrazinyl) pyrazine (CHP1)}

Yellow solid, mp: $196-198{ }^{\circ} \mathrm{C}$, yield: $87 \%$, molecular weight (Mw): $262.69 \mathrm{~g} / \mathrm{mol}, \lambda_{\max }(\mathrm{DMF}): 365 \mathrm{~nm}$. FT-IR $\left(\mathrm{KBr}, \mathrm{cm}^{-1}\right): 610(\mathrm{C}-\mathrm{Cl}), 1170(\mathrm{C}-\mathrm{N}), 1242(\mathrm{C}-\mathrm{O})$, $1511(\mathrm{C}=\mathrm{C}), 1647(\mathrm{C}=\mathrm{N}), 3248(\mathrm{~N}-\mathrm{H}),{ }^{1} \mathrm{H}$ NMR $\left(400 \mathrm{MHz}, \mathrm{CDCl}_{3}, \delta(\mathrm{ppm})\right): 3.86\left(\mathrm{~s}, 3 \mathrm{H}, \mathrm{OCH}_{3}\right), 6.94$ $(\mathrm{d}, 2 \mathrm{H}, \mathrm{CH}, J=8.8 \mathrm{~Hz}), 7.73(\mathrm{~d}, 2 \mathrm{H}, \mathrm{CH}, J=8.4 \mathrm{~Hz}), 7.81$ $(\mathrm{dd}, 1 \mathrm{H}, \mathrm{CH} J=2.4 \mathrm{~Hz}), 8.07(\mathrm{~s}, 1 \mathrm{H}, \mathrm{CH}), 8.21(\mathrm{dd}, 1 \mathrm{H}$, $\mathrm{CH}, J=2.4 \mathrm{~Hz}), 8.58(\mathrm{~s}, 1 \mathrm{H}, \mathrm{NH}) .{ }^{13} \mathrm{C}$ NMR $(100 \mathrm{MHz}$, $\left.\mathrm{CDCl}_{3}, \delta(\mathrm{ppm})\right): 55.39,109.94,114.20,126.30,129.04$, $133.31,141.52,146.01,147.52,161.33$.
(E)-3-((2-(3-chloropyrazin-2-yl)hydrazineylidene) methyl)-6-methyl-4H-chromen-4-one (CHP2)

Yellow solid, mp: $265-268{ }^{\circ} \mathrm{C}$, yield: $85 \%$, Mw: $314.76 \mathrm{~g} /$ mol, $\lambda_{\max }(\mathrm{DMF}): 365 \mathrm{~nm}$.

FT-IR $\left(\mathrm{KBr}, \mathrm{cm}^{-1}\right): 719(\mathrm{C}-\mathrm{Cl}), 1170(\mathrm{C}-\mathrm{N}), 1207$ $(\mathrm{C}-\mathrm{O}), 1518(\mathrm{C}=\mathrm{C}), 1645(\mathrm{C}=\mathrm{N}), 1665(\mathrm{C}=\mathrm{O}), 3256$ $(\mathrm{N}-\mathrm{H}) .{ }^{1} \mathrm{H}$ NMR $\left(400 \mathrm{MHz}, \mathrm{CDCl}_{3}, \delta(\mathrm{ppm})\right): 2.51$ $\left(\mathrm{s}, 3 \mathrm{H}, \mathrm{CH}_{3}\right), 7.46(\mathrm{~d}, 1 \mathrm{H}, \mathrm{CH}, J=8.8 \mathrm{~Hz}), 7.56(\mathrm{~d}, 1 \mathrm{H}$, $\mathrm{CH} J=8.8 \mathrm{~Hz}), 7.88(\mathrm{~s}, 1 \mathrm{H}, \mathrm{CH}), 8.09(\mathrm{~s}, 1 \mathrm{H}, \mathrm{CH}), 8.23$ $(\mathrm{s}, 1 \mathrm{H}, \mathrm{CH}), 8.41(\mathrm{~s}, 1 \mathrm{H}, \mathrm{CH}), 8.74(\mathrm{~s}, 1 \mathrm{H}, \mathrm{CH}), 8.77$ (s, 1H, NH). ${ }^{13} \mathrm{C}$ NMR $\left(100 \mathrm{MHz}, \mathrm{CDCl}_{3}, \delta(\mathrm{ppm})\right)$ : 21.04, 118.30, 125.36, 125.4, 133.8, 134.1, 134.3, 135.50, $135.54,136.05,136.11,138.51,141.37,153.98$.

(E)-3-((2-(3-chloropyrazin-2-yl)hydrazineylidene)methyl) phenol (CHP3)

Yellow solid, mp: $210-215{ }^{\circ} \mathrm{C}$, yield: $89 \%$, Mw: $248.67 \mathrm{~g} /$ mol, $\lambda_{\max }$ (DMF): $365 \mathrm{~nm}$.

FT-IR $\left(\mathrm{KBr}, \mathrm{cm}^{-1}\right): 689(\mathrm{C}-\mathrm{Cl}), 1170(\mathrm{C}-\mathrm{N}),(\mathrm{C}-\mathrm{O})$, $1666(\mathrm{C}=\mathrm{N}), 3291(\mathrm{O}-\mathrm{H}), 3420(\mathrm{~N}-\mathrm{H}) .{ }^{1} \mathrm{H}$ NMR $\left(400 \mathrm{MHz}, \mathrm{CDCl}_{3}, \delta(\mathrm{ppm})\right): 6.80(\mathrm{~d}, 1 \mathrm{H}, \mathrm{CH}, J=8 \mathrm{~Hz})$, $7.08(\mathrm{~d}, 1 \mathrm{H}, \mathrm{CH}, J=7.6 \mathrm{~Hz}), 7.24(\mathrm{~m}, 2 \mathrm{H}, \mathrm{CH}), 7.85$ $(\mathrm{s}, 1 \mathrm{H}, \mathrm{CH}), 8.23(\mathrm{~s}, 1 \mathrm{H}, \mathrm{CH}), 8.43(\mathrm{~s}, 1 \mathrm{H}, \mathrm{CH}), 9.59$ (s, 1H, OH), 10.77 (s, 1H, NH). ${ }^{13} \mathrm{C}$ NMR $(100 \mathrm{MHz}$, $\left.\mathrm{CDCl}_{3}, \delta(\mathrm{ppm})\right): 112.76,117.35,118.87,130.32,132.91$, $133.79,136.52,141.97,146.31,148.37,158.11$.

\section{(E)-2-((2-(3-chloropyrazin-2-yl)hydrazineylidene)methyl) phenol (CHP4)}

Brown solid, mp: $140-144{ }^{\circ} \mathrm{C}$, Mw: $248.67 \mathrm{~g} / \mathrm{mol}, \lambda_{\max }$ (DMF): $386 \mathrm{~nm}$.

FT-IR $\left(\mathrm{KBr}, \mathrm{cm}^{-1}\right): 747(\mathrm{C}-\mathrm{Cl}), 1053(\mathrm{C}-\mathrm{N}), 1168$ $(\mathrm{C}-\mathrm{O}), 1666(\mathrm{C}=\mathrm{N}), 3287(\mathrm{O}-\mathrm{H}), 3420(\mathrm{~N}-\mathrm{H}) .{ }^{1} \mathrm{H}$ NMR $\left(400 \mathrm{MHz}, \mathrm{CDCl}_{3}, \delta(\mathrm{ppm})\right): 6.93(\mathrm{~d}, 2 \mathrm{H}, \mathrm{CH}$, $J=9.2 \mathrm{~Hz}), 7.29(\mathrm{t}, 1 \mathrm{H}, \mathrm{CH}, J=7.6 \mathrm{~Hz}), 7.46(\mathrm{~d}, 1 \mathrm{H}$, $\mathrm{CH}, \mathrm{J}=7.6 \mathrm{~Hz}), 7.89(\mathrm{~s}, 1 \mathrm{H}, \mathrm{CH}), 8.27(\mathrm{dd}, 1 \mathrm{H}, \mathrm{CH}$, $J=1.6 \mathrm{~Hz}), 8.70(\mathrm{~s}, 1 \mathrm{H}, \mathrm{CH}), 11.2(\mathrm{~s}, 1 \mathrm{H}, \mathrm{OH}), 11.55(\mathrm{~s}$, $1 \mathrm{H}, \mathrm{NH}) .{ }^{13} \mathrm{C} \mathrm{NMR}\left(100 \mathrm{MHz}, \mathrm{CDCl}_{3}, \delta\right.$ (ppm)): 116.89, $119.32,119.74,130.09,131.20,132.98,134.20,142.08$, 147.36, 147.86, 157.69 .

\section{(E)-2-chloro-3-(2-(4-chlorobenzylidene)hydrazineyl)pyrazine (CHP5)}

Brown solid, mp: $201-204{ }^{\circ} \mathrm{C}$, yield: $92 \%$, Mw: $267.11 \mathrm{~g} /$ mol, $\lambda_{\max }(\mathrm{DMF}): 390 \mathrm{~nm}$.

FT-IR $\left(\mathrm{KBr}, \mathrm{cm}^{-1}\right)$ : $707(\mathrm{C}-\mathrm{Cl}), 1168(\mathrm{C}-\mathrm{O}), 1487$ $(\mathrm{C}=\mathrm{C}), 1647(\mathrm{C}=\mathrm{N}), 3207(\mathrm{~N}-\mathrm{H}) .{ }^{1} \mathrm{H}$ NMR $(400 \mathrm{MHz}$, $\left.\mathrm{CDCl}_{3}, \delta(\mathrm{ppm})\right): 7.52(\mathrm{~d}, 2 \mathrm{H}, \mathrm{CH}, J=7.2 \mathrm{~Hz}), 7.73(\mathrm{~d}$, $2 \mathrm{H}, \mathrm{CH}, J=7.2 \mathrm{~Hz}), 7.87(\mathrm{dd}, 1 \mathrm{H}, \mathrm{CH}, \mathrm{J}=2 \mathrm{~Hz}), 8.26(\mathrm{~s}$, $1 \mathrm{H}, \mathrm{CH}), 8.50(\mathrm{~s}, 1 \mathrm{H}, \mathrm{CH}), 10.92(\mathrm{~S}, 1 \mathrm{H}, \mathrm{NH}) .{ }^{13} \mathrm{C} \mathrm{NMR}$ 
(100 MHz, $\mathrm{CDCl}_{3}, \delta$ (ppm)): 128.73, 129.37, 133.01, $134.10,134.23,134.29,142.01,144.70,148.29$.

\section{In vitro assessments}

\section{AChE inhibition assay}

The AChE inhibitory activity of all synthesized novel derivatives and their controls was evaluated through using the Ellman method. In addition, the AChE (Sigma, EC number 3.1.1.7, CAS number 9000.81.1) from Electrophorus electricus was utilized in the study [25]. Further, $4 \mu \mathrm{L}$ of enzyme solution ( $1 \mathrm{ng}$ commercial enzyme, Tris- $\mathrm{HCl}, \mathrm{pH} 7.4$, final concentration of $0.1 \mathrm{mg} / \mathrm{mL}$ ), $60 \mu \mathrm{L}$ of $15 \mathrm{mM}$ ATCI in $40 \mu \mathrm{L}$ of water, $500 \mu \mathrm{L}$ of $5 \mathrm{mM}$ DTNB in Buffer B $(0.1 \mathrm{mg} / \mathrm{mL}$ Tris- $\mathrm{HCl}, \mathrm{pH} 7.4$, containing $100 \mathrm{mM} \mathrm{K3PO} 4$ and $1 \mathrm{mM}$ EDTA), and $10 \mu \mathrm{L}$ of compounds $(0.1-10 \mu \mathrm{M})$ were poured in a 96-well plate. Each concentration was assayed in triplicate. Furthermore, all of the synthesized compounds (CHP1-5) and their bases were dissolved in DMSO. Finally, absorbance was recorded by using a Pharmacia Biotech Ultrospec $3000 \mathrm{UV}-\mathrm{V}$ is spectrophotometer at $410 \mathrm{~nm}$.

\section{Antioxidant activity}

The radical scavenging activity of prepared compounds was assessed through using ABTS decolorization assay and method reported by Re et al. [26] with few modifications. In this regard, ABTS solution was diluted with $80 \%$ ethanol to the absorbance of $0.70 \pm 0.05$ at $734 \mathrm{~nm}$. After adding $100 \mu \mathrm{L}$ of the obtained compounds in ethanol (1-30 $\mu \mathrm{M})$ or ascorbic acid, absorbance was measured at exactly $20 \mathrm{~min}$ in the same wavelength. DPPH assay was based on the method provided by Ghafouri et al. [27] with some modifications. Additionally, the quenching of free radicals by novel synthesized compounds was evaluated spectrophotometrically (UV-Vis Pharmacia Biotech Ultrospec 3000) at $517 \mathrm{~nm}$ against the absorbance of DPPH radical. Further, ferric reducing/antioxidant power (FRAP) assay was performed according to the previous study with some modifications [27], the principle of which was based on reducing a ferric 2,4,6-tris(2pyridyl)-1,3,5-triazine ( $\mathrm{Fe}^{3+}$-TPTZ) to ferrous in the presence of prepared compounds. Finally, a standard curve was drawn by considering the different concentrations $(10-1000 \mu \mathrm{M})$ of ferrous sulfate.

\section{Cell viability}

Rattus norvegicus pheochromocytoma PC12 cells (Pastor Institute, Iran) were cultured in the Dulbecco's Modified Eagle's Medium (DMEM) containing 10\% fetal bovine serum (FBS) and 1\% penicillin/streptomycin (Gibco) at $37^{\circ} \mathrm{C}$ with $5 \% \mathrm{CO}_{2}$. In order to examine the role of CHP4, PC12 cells were treated with the different concentrations $(10-100 \mu \mathrm{M})$ of CHP4 for 24 and $48 \mathrm{~h}$. In addition,
Ab1-42 peptides were dissolved in distilled water and primarily incubated at $37^{\circ} \mathrm{C}$ for $7 \mathrm{~d}$ before using for constructing pre-aggregation. Further, PC12 cells were incubated with $100 \mu \mathrm{M}$ aggregated Ab1-42 for $24 \mathrm{~h}$ to make a cellular AD model in vitro. Furthermore, $50 \mu \mathrm{L}$ of DMSO and $10 \mu \mathrm{L}$ of $0.5 \mathrm{mg} / \mathrm{mL}$ MTT stock solution were added to each well containing about $1 \mathrm{~mL}$ of medium and the mixture was incubated for $4 \mathrm{~h}$. Then, the plates were agitated on a plate shaker for $30 \mathrm{~min}$ and optical density was read at $570 \mathrm{~nm}$ by using an ELISA reader (Biotech). A slightly-modified MTT method of Jamalzadeh et al. [28] was employed in the experiments and the cell viability of the control groups not exposed to CHP4 or Ab1-42 was defined as $100 \%$.

\section{Western blot analysis}

To this end, the cells were seeded in the 6-well plate and treated with 20 and $30 \mu \mathrm{M} \mathrm{CHP} 4$ for $24 \mathrm{~h}$. Additionally, they were washed with cold PBS, followed by lysing with lysis buffer (20 mM Tris (pH 7.5), $150 \mathrm{mM} \mathrm{NaCl}, 1 \mathrm{mM}$ EDTA, 1\% NP-40, 0.5\% sodium deoxycholate, 0.1\% SDS, $50 \mathrm{mM}$ Tris, protease and phosphatase inhibitor cocktails) for $30 \mathrm{~min}$ on ice. After centrifuging lysates at $4{ }^{\circ} \mathrm{C}$ in $12,000 \mathrm{~g}$ for $10 \mathrm{~min}$, the supernatants were transferred to new tubes. Protein concentration was detected through using the Bradford assay [29]. Further, the denatured proteins was resolved on SDS-PAGE, transferred onto PVDF membranes (Millipore, Billerica, MA, USA), and blocked with $5 \%$ nonfat dry milk in the PBS containing $0.1 \%$ Tween-20 (PBST). Then, the membranes were incubated with the rabbit primary antibodies against Tau-p, HSP70, and $\beta$-actin (as a control group) overnight at $4{ }^{\circ} \mathrm{C}$, and exposed with the horseradish peroxidase (HRP)-conjugated second antibody for $2 \mathrm{~h}$ at room temperature. Finally, the density of relative protein bands was determined through densitometric scanning the blots by using Image-J program.

\section{In silico studies}

\section{Geometry optimization, MEP and molecular descriptors}

Geometry optimization of all five compounds was performed at DFT level theory with B3LYP hybrid exchange-correlation energy functional method and 6-31G++ (d, p) basis by Gaussian 09 software [30]. From the optimized structures, the molecular electrostatic potential (MEP) of each compound was calculated by the same software and visualized using GaussView v. 6. The capability of molecules to permeate blood-brain barrier (BBB) was predicted by Online BBB Predictor [31] and other descriptors related to drug likeness property of each compound was calculated through using Padel descriptor [32]. 


\section{Docking}

AutoDock Vina software program was applied for docking CHP4 into hAChE protein [33]. In addition, the X-ray crystallographic structure of human AChE (PDB ID: 6O4W, $2.35 \AA$ resolution) was obtained from the RCSB protein data bank (PDB). The protein was prepared through removing water, co-factor, and co-crystallized ligands by MolSoft ICM [34]. Further, the 2D structure of CHP4 was drawn using MarvinSketch (version 16.8.15) by ChemAxon and converted to 3D format by using molconverter from Jchem toolkit (http://www.chema xon.com). All docking calculations were performed by considering the protein and ligand as inflexible and flexible, respectively. Furthermore, donepezil (DPZ) was docked into $6 \mathrm{O} 4 \mathrm{~W}$ as a positive control ligand to validate the docking protocol. Finally, the Vina output file was entered into ADT for analyzing the docking results, and the hydrophobic interactions of AChE-ligand complexes, as well as bond lengths were examined.

\section{Analysis of binding sites and conserved sequences}

For the purpose of identification of conserved sequences of AChE from an evolutionary aspect, ConSurf software was used with HMMER homolog search algorithm, MAFFT-L-INS-i method for alignments and Bayesian method for calculations [35].

\section{Statistical analysis}

Each concentration was assayed in triplicates $(n=3)$ and repeated in three independent experiments. The values were expressed as mean \pm SD and one-way ANOVA was utilized to determine the significant differences from controls statistically.

\section{Results and discussion \\ Chemistry \\ Spectroscopic characterization of the pyrazine-based \\ Schiff-bases}

In the present study, five pyrazine-based Schiff-bases were synthesized through condensation reaction, the synthetic pathways for which are presented in Fig. 1. The chemical structure of compounds was approved by FT-IR, and ${ }^{13} \mathrm{C}$ and ${ }^{1} \mathrm{H}$ NMR spectroscopic data (see spectrums in Additional file 1). Additionally the UV-Vis spectra of all compounds were measured between 200 and $800 \mathrm{~nm}$, which their $\lambda_{\max }$ was $365-390 \mathrm{~nm}$ due to $\mathrm{n}-\pi \star$ and/or $\pi-\pi \star$ electronic transitions.

\section{In vitro}

\section{AChE inhibition assay}

All of obtained imine derivatives (CHP1-5) were evaluated for their inhibitory activities toward AChE through using an in vitro assay based on the reported protocol in comparison with donepezil as a standard drug $\left(\mathrm{IC}_{50}=0.53 \mu \mathrm{M}\right)$. The preliminary results in Fig. $2 \mathrm{dem}$ onstrated the highest AChE inhibitory effect in CHP4 with a hydroxyl group in the formyl $\left(\mathrm{IC}_{50}=3.76 \mu \mathrm{M}\right)$. In fact, the activity of the synthesized imine derivatives depends on the nature of the substituents attached to formyl group.

\section{Antioxidant properties}

The $\mathrm{ABTS}^{+}$radical is created by oxidizing ABTS with potassium persulfate and reduced in the presence of such hydrogen-donating antioxidant compound. The results were obtained at the final concentration $(1-30 \mu \mathrm{M})$ of compounds and their inhibition was assessed. The<smiles>NNc1nccnc1Cl</smiles>

(A)

(B)

CHP1-CHP5<smiles>[Y]c1cccc(O)c1</smiles>

Fig. 1 Synthesized pathways for the pyrazine-based compounds (CHP1-CHP5) 


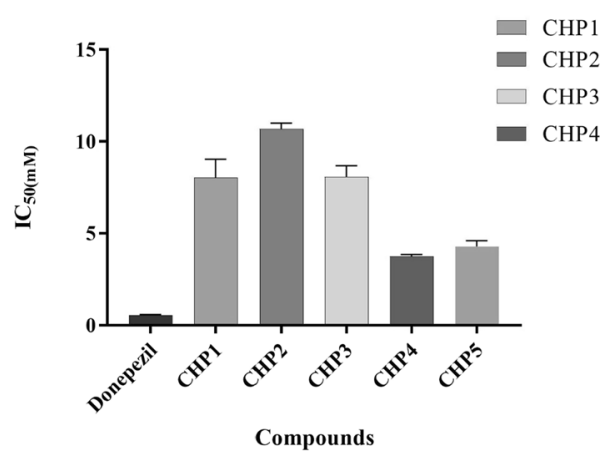

Fig. $2 \mathrm{IC} 50(\mu \mathrm{M})$ values of synthesized compounds against AChE activity $(\mathrm{IC} 50=0.53 \mu \mathrm{M})$. CHP $4>\mathrm{CHP} 5>\mathrm{CHP} 3>\mathrm{CHP} 1>\mathrm{CHP} 2$. The data are expressed in relation to $\mathrm{AChE}$ activity with respect to control as mean $\pm S D(n=3, P<0.001)$. Donepezil is used as a positive control

compounds were tested to determine by decolorizing the ABTS radical and assessed as a quenching of the absorbance at $734 \mathrm{~nm}$. Based on the results, CHP1 exhibited high scavenging activity (48\%) (Fig. 3A). Figure $3 \mathrm{~B}$ compares the antiradical effect of compounds at various concentrations compared to that of ascorbic acid, which indicates the lower activity of all compounds. Further, the DPPH-reducing abilities of all compounds were measured by determining their $\mathrm{IC}_{50}$ values. As shown in Fig. 3B, the highest scavenging activity on $\mathrm{DPPH}^{*}$ are respectively observed in $\mathrm{CHP} 2, \mathrm{CHP} 4$, and $\mathrm{CHP} 3$, while CHP1 and CHP5 represent moderate and low properties, respectively. Furthermore, the antioxidant activity of all compounds was estimated by considering their ability to reduce TPRZ-Fe (III) complex to the TPTZ-Fe (II), the results of which are displayed in Fig. 3C. The concentration values of $\mathrm{Fe}^{2+}$ exhibited significant antioxidant properties in all synthesized compounds. Finally, the highest and least antioxidant effect was respectively obtained in CHP4 and CHP5.

\section{Cell viability assays}

In order to examine the neuroprotective effects of CHP4 against the Ab1-42-induced toxicity, PC12 cells were treated with CHP4 in the presence or absence of $100 \mu \mathrm{M}$ Ab1-42 for $24 \mathrm{~h}$. Then, cell viability was determined through using MTT assay. As depicted in Fig. 4, the viability of the PC12 cells exposed to $100 \mu \mathrm{M}$ Ab1-42 for $24 \mathrm{~h}$ decreased to $49.24 \%$ compared to the control group. In addition, CHP4 significantly reduced the Ab1-42-induced cell death in a dose-dependent manner (Fig. 5). In the assays, the cell viability of the control group not exposed to CHP4 or Ab1-42 was considered as $100 \%$.

In the pathological conditions, tau can be more phosphorylated than the normal phosphorylation, which is AD hallmarks [36]. Based on the western blot results of Tau-p and HSP70 in the PC12 cell treated with CHP4 and in the presence of Ab1-42, the level of tau phosphorylation increased significantly in the $+\mathrm{A} \beta 1-42$ group compared to the control. However, Tau-p expression clearly decreased in response to $\mathrm{CHP} 4$ at the final concentration of 20 and $30 \mu \mathrm{M}$. Also donepezil is utilized as a positive control (Fig. 6). Original photos of western blot gel are available, in Additional file 1.

\section{In silico studies}

MEP

First, the optimized structural properties of all compounds, which can be found in supplementary information, were obtained at DFT level of theory. The colored scheme of MEP visualization is presented in Fig. 7. The darkest red color indicates the most electron-rich region, capable of acting as one of the best hydrogen bond

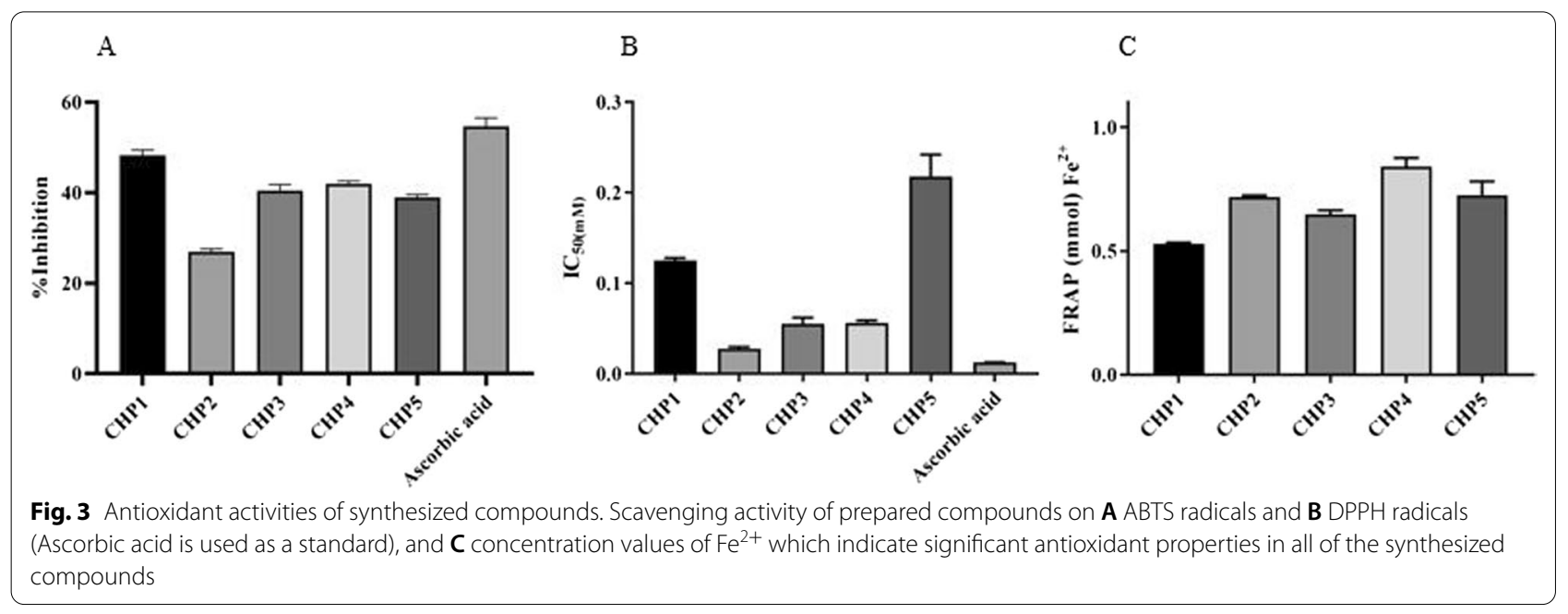


A

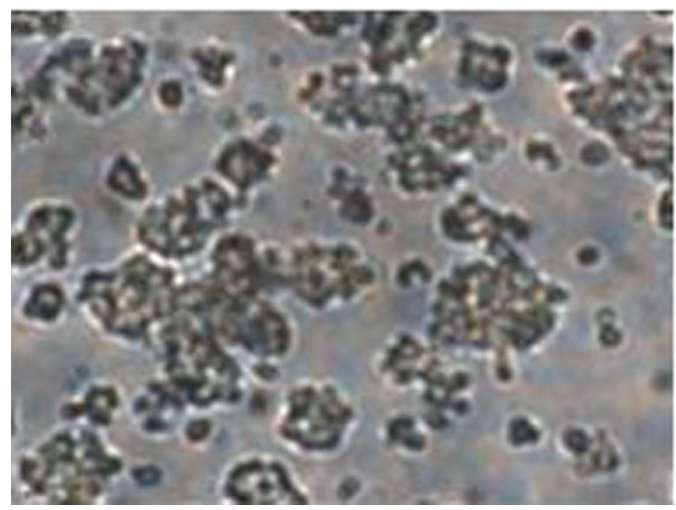

B

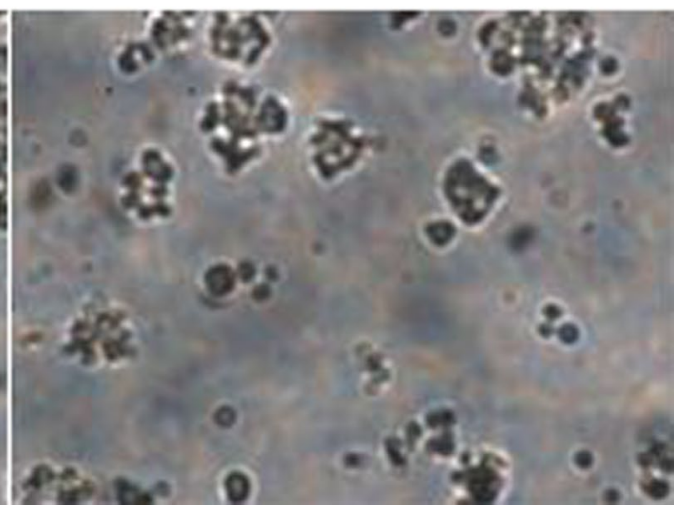

Fig. 4 PC12 cells exposed to the Ab1-42 peptides in the $\mathbf{A}$ absence or $\mathbf{B}$ presence of $100 \mu \mathrm{M}$ Ab1-42

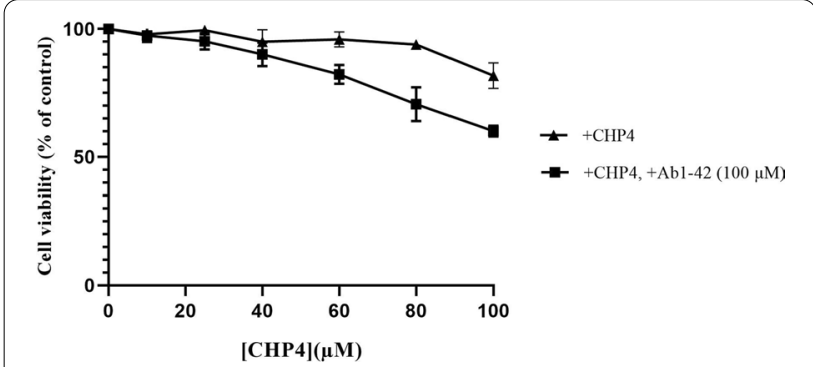

Fig. 5 Protective effects of $\mathrm{CHP} 4$ at various concentrations against the $A \beta 1-42 . A B 1-42(100 \mu M)$-induced cytotoxicity in PC12 neuronal cells (Cell viability was assayed through using MTT. The values are presented as the mean \pm SD of three independent experiments. The cell viability of the control group not exposed to either CHP4 or Ab1-42 is defined as $100 \%$.)

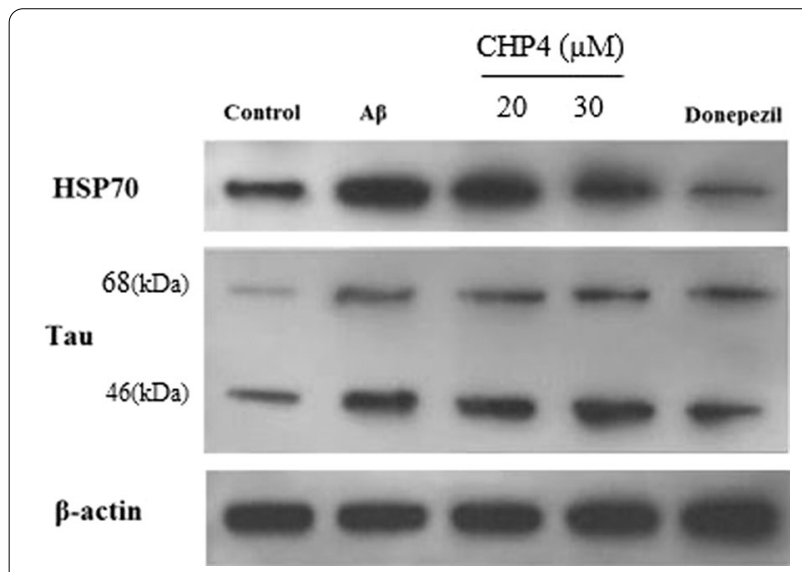

Fig. 6 Representative western blot analysis of Tau-p and HSP70 in the PC12 cell treated with CHP4 acceptors, whereas the darkest blue color represent the site which is the most sensitive towards nucleophilic attacks [37]. As can be seen in Fig. 7, except for CHP2 that has its most electron-rich region located at its carbonyl group, the same region is located at $\mathrm{N}_{6}$ of other compounds. Additionally, while CHP1, CHP2 and CHP4 have their least electron-rich regions at their $\mathrm{N}-\mathrm{H}$ of hydrazine group, for $\mathrm{CHP} 3$ and $\mathrm{CHP} 4$ it is related to the phenolic hydrogen.

\section{Drug likeness properties of the compounds}

First, it was predicted that all compounds are capable of passing from $\mathrm{BBB}$ and their diagrams are presented in supplementary information. Lipinski's rule of five was employed as the basis of investigating the drug likeness properties of compounds. According to this rule, an ideal drug candidate must not have more than 5 hydrogen bond donors, more than ten hydrogen bond acceptors, a molecular mass less than $500 \mathrm{Da}$ and $\log \mathrm{P}$ more than 5 [38]. As has been represented in Table 1, apart from the molecular mass, other criteria of the rule apply to the studied compounds.

\section{Molecular docking of CHP4 and donepezil}

Following the end of docking process, the best conformation was selected and the scoring functions indicated that conformations were the best complement to the AChE. Additionally, AutoDock 4.2 software was applied for all of the docking calculations (see vina results in the Additional file 1). The docking of CHP4 affinity with active site was calculated as $-8.3 \mathrm{kcal} /$ mol. D72, W84, N85, Y121, S122, F330, Y334 and F331 were the residues interacting with CHP4. Moreover, the evolutionary analysis of $\mathrm{AChE}$ revealed that out of this 

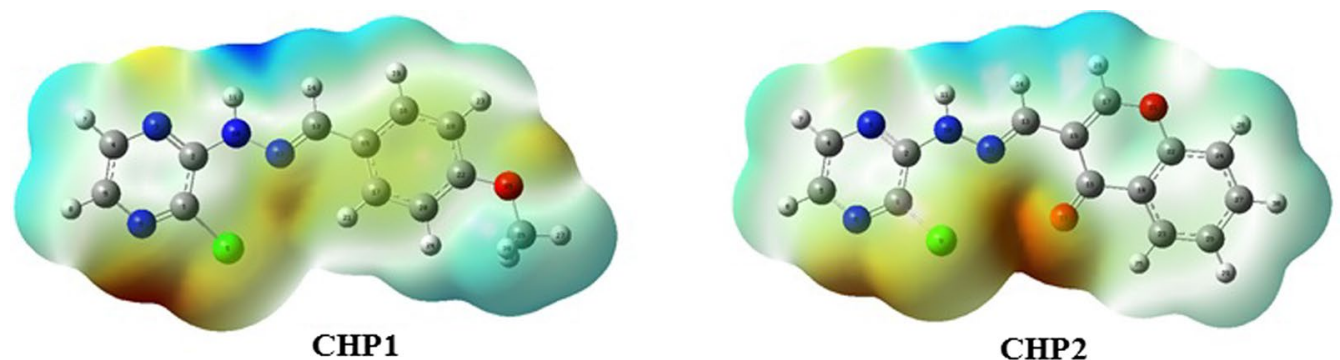

CHP2
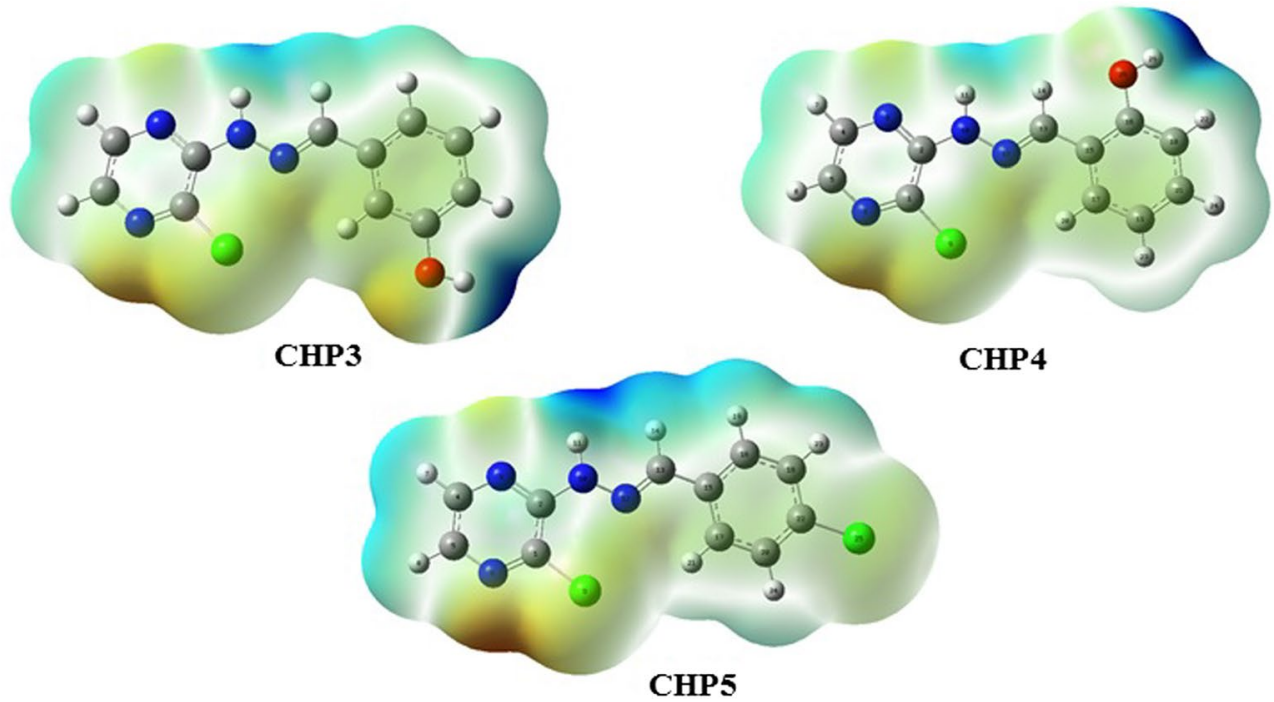

CHP4

CHP5

Fig. 7 MEP of CHP1 to CHP5. For CHP1 MEP is represented from - 4.636 a.u. to + 4.636 a.u., for CHP2 it is from - 4.646 a.u. to + 4.646 a.u., for CHP3 from - 6.529 a.u. to + 6.529 a.u., for CHP4 from - 7.159 a.u. to + 7.159 a.u. and for CHP5 from - 5.104 a.u. to + 5.104 a.u. The most electron rich region for all compounds, except for $\mathrm{CHP2}$, is located at $\mathrm{N}_{6}$ and for $\mathrm{CHP}_{2}$ it is $\mathrm{O}_{19}$. Furthermore, the least electron rich region for $\mathrm{CHP1}$, $\mathrm{CHP2}$ and CHP5 is at $\mathrm{H}_{11}$ but for $\mathrm{CHP} 3$ and $\mathrm{CHP} 4$ it is $\mathrm{H}_{26}$

Table 1 Drug-likeness properties of CHP1 to CHP4

\begin{tabular}{llllll}
\hline Descriptor & CHP1 & CHP2 & CHP3 & CHP4 & CHP5 \\
\hline Hydrogen bond donor & 1 & 1 & 2 & 2 & 1 \\
$\begin{array}{l}\text { Hydrogen bond accep- } \\
\text { tor }\end{array}$ & 5 & 6 & 5 & 5 & 4 \\
$\begin{array}{l}\text { AlogP } \\
\text { Number of rotatable }\end{array}$ & 0.027 & 0.054 & -0.380 & -0.380 & 0.82 \\
bonds & & 5 & 3 & 3 & 3 \\
$\begin{array}{l}\text { Polar surface area } \\
\text { Molecular mass }\end{array}$ & 59.4 & 76.47 & 70.4 & 70.4 & 50.17 \\
Number of atoms & 262.062 & 314.057 & 248.046 & 248.046 & 266.012 \\
\hline
\end{tabular}

residues, Y121 is highly conserved. In order to validate the docking results obtained by Vina software, donepezil was docked in $6 \mathrm{O} 4 \mathrm{~W}$ as positive control ligand (RMSD: $0.307 \AA$ ) with an affinity of $-12.8 \mathrm{kcal} / \mathrm{mol}$ (Table 2). After docking, the interaction of CHP4 with AChE was evaluated by using UCSF Chimera [39] and
LigPlot [40] software (Fig. 8). More figures are available in the additional file. Finally.

\section{Discussion}

Designing, synthesizing, and producing the molecules valuable as human therapeutic agents are considered one of the principal purpose of pharmaceutical and organic chemistry. Pyrazines possess various types of biological activity, which represents a range of their pharmacological activities such as antibacterial, antimycobacterial, antiviral, antifungal, anti-diabetic, anti-cancer, analgesic, hypnotic, diuretic [23], and anticholinergic ones [41, 42]. In the present study, several novel 2-chloro-3-hydrazinopyrazine derivatives were designed, synthesized, and evaluated, which their pyrazine base was effective (Fig. 1). Pyrazine is an aromatic heterocyclic ring, which contains two nitrogen atoms with the general effect of protonation and hydrogen-bond formation [43]. The molecular characteristics of all of the synthesized compounds (Table 1), indicated that these molecules have 
Table 2 List of amino acids involved in hydrogen bonding and hydrophobic interactions with CHP4 and donepezil with AChE

\begin{tabular}{|c|c|c|c|c|}
\hline \multirow[t]{2}{*}{ Compounds } & \multicolumn{2}{|c|}{ UCSF Chimera } & \multicolumn{2}{|l|}{ LigPlot+ } \\
\hline & H-bonds & $\mathrm{HI}$ & H-bonds & $\mathrm{HI}$ \\
\hline $\mathrm{CHP} 4$ & $S 124 b$ & $\begin{array}{l}\text { Chain b: } \\
\text { W84, Y121, D72, S122, } \\
{ }^{*} \text { F331, *Y334, *F330, N85 }\end{array}$ & Y121b & $\begin{array}{l}\text { Chain b: } \\
\text { W84, Y121, D72, S122, *F331, *Y334, *F330, N85 }\end{array}$ \\
\hline DPZ & $\mathrm{S} 228 b, \mathrm{~S} 205 b$ & $\begin{array}{l}\text { Chain b: } \\
\text { F288, A234, W233, *F331, C231, S288,A204, P229, } \\
\text { F290, N230, F120, M208, S200, I287, *F330, N399, } \\
\text { S235, V395, L332, *Y334, V400 }\end{array}$ & - & $\begin{array}{l}\text { Chain b: } \\
\text { F288, A234, *F331, C231, S288,A204, P229, F290, N230, } \\
\text { F120, M208, *F330, N399, S235, V395, L332, *Y334, V400 }\end{array}$ \\
\hline
\end{tabular}

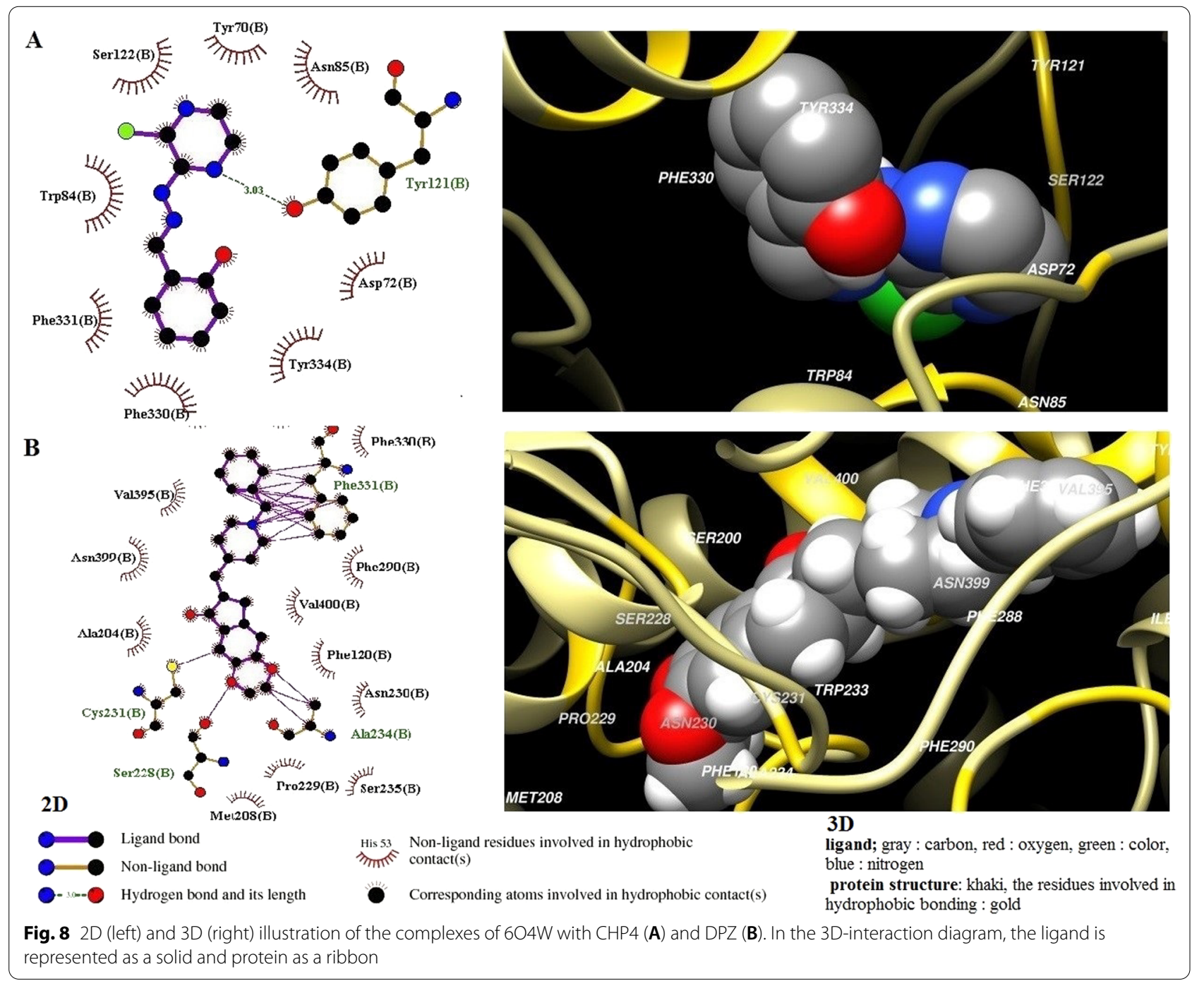

potential as drug candidates. In the $\mathrm{AD}$ therapy, one of the aims of treatment is to inhibit AChE [44]. Accordingly, some novel compounds have been produced for assessing the inhibitory effects on AChE. In this study, the inhibitory effects of the novel compounds on AChE were assessed and the relationship between AChE inhibitory activity with the chemical structures of the compounds was evaluated. Based on the preliminary results, CHP4 with a hydroxyl group at the ortho position of $N$-phenyl ring exhibited the highest $\mathrm{AChE}$ inhibitory effect $\left(\mathrm{IC}_{50}=3.76 \mu \mathrm{M}\right)$. The 
effectiveness of CHP4 may be related to the electron withdrawing property of the phenyl ring [45]. Computational analysis illustrated that CHP4 is capable of having hydrogen interaction with Tyr121 through its nitrogen of pyrazine ring (Fig. 8), which is the most electron-rich region of the compound according to MEP and the same residue in the protein is a highly conserved sequence from an evolutionary aspect. According to Uysal et al., the formation of mono- and di-substituents to the ortho position of $N$-phenyl ring improved AChE inhibitory effect slightly [46]. Furthermore the hydroxyl group was not involved in hydrogen bonding with $\mathrm{AChE}$, in spite the fact that its hydrogen possesses the least electron-rich region of the molecule based on MEP [47].

In the $\mathrm{AD}$ patients, the use of antioxidant therapies for the disease is necessary to reduce pathogenic symptoms [48]. The results of the present study demonstrated that CHP2 represented the most potent antioxidant properties $\left(\mathrm{IC}_{50}=0.026 \mathrm{mM}\right)$ in the $\mathrm{DPPH}$ assay due to its higher capacity to donate electron compared to the others (CHP2 $>\mathrm{CHP} 3>\mathrm{CHP} 4>\mathrm{CHP} 1>\mathrm{CHP} 5)$. In the ABTS assay, CHP1 performed better than the others due to the presence of electron-withdrawing and electron-donating group, methoxy group, with $48 \%$ inhibition (CHP1 $>$ CHP4 $>$ CHP3 > CHP5 $>$ CHP2). Furthermore, FRAP assay is based on the ability of antioxidants to reduce $\mathrm{Fe}^{3+}$ to $\mathrm{Fe}^{2+}$. The highest ability for $\mathrm{Fe}^{3+}$ reduction was observed in CHP4 (3.016 per $1 \mathrm{mM})(\mathrm{CHP} 4>\mathrm{CHP} 2>\mathrm{CHP} 5>\mathrm{CHP} 3>\mathrm{CHP} 1)$. The ortho position of a hydroxyl group on benzoic ring exhibited excellent antioxidant activity, while the meta position led to weak effect [49]. Based on previous studies and due to the toxicity of iron and its important role in the progression of $\mathrm{AD}$ [50-52], CHP4 was selected for following the study.

$\mathrm{AD}$ is a common neurodegenerative diseases, the hallmark pathologic characteristics of $A \beta$ plaques, tau hyperphosphorylation, and neuronal cell death [2]. HSP70 and some of the other co-chaperones are involved in regulating, phosphorylation, aggregation and degradation of tau, and potentially implicated in pathogenesis of AD [5356]. In the present study, the protective effect of CHP4 was examined against Ab1-42 toxicity in PC12 neuronal cells, the results of which reflected that $\mathrm{CHP} 4$ at therapeutic-relevant concentration protected and rescued neuronal cells from the toxicity of Ab1-42 peptide.

In addition, the effects of CHP4 on the expression of Tau-p and HSP70 were assessed using western blot analysis, which demonstrates that the exposure of CHP4 resulted in decreasing the Ab1-42-induced phosphorylation of tau and increased HSP70 expression. According to Lu et al., HSP700 plays cytoprotective roles in AD, blocks $\mathrm{A} \beta$ self-assembly, moderates caspase-dependent and caspase-independent apoptotic pathways and reduces it in neuron cells, it also directly prevents tau aggregation and enhance $A \beta$ clearance by upregulates the expression of insulin degrading enzyme and transforming growth factor beta [57]. Some studies have reported the protective role of HSP70 in the CNS, while several others have found the pathological and detrimental role of HSP70 in AD. In fact, HSP70 acts as a double-sided sword and its role in AD is still unclear and controversial. According to Miyata et al., HSP70 is considered as an emerging pharmaceutical target for treating neurodegenerative tauopathies [58].

\section{Conclusion}

In summary, five compounds (CHP1-CHP5) were designed, synthesized, and evaluated. In the following, all synthesized compounds were analyzed and identified by using IR, 1H and 13C NMR. Novel compounds have been assayed for assessing the inhibitory effects on $\mathrm{AChE}$, which CHP4 was effective (IC50 $=3.76 \mu \mathrm{M})$. According to the results of DPPH, ABTS and FRAP assays, CHP4 was chosen for subsequent the study. We have shown that CHP4 has a protective effect on $\mathrm{PC} 12$ neuronal cells against the toxicity of Ab1-42 peptide. In supplemental studies of western blot analysis, CHP4 reduce the expression of Tau-p as an important cause to AD On the other hand, a decrease in HSP70 expression was also seen, which could be a sign of a diminish in the pathological symptoms of this disease.

The multifunctional properties (an optimal strategy) highlight CHP4 as a promising candidate for further studies on the development of novel drugs against AD. However, more extensive research should be conducted to assess the exact mechanism of effectiveness, as well as dose and potential in medical applications.

\section{Supplementary Information}

The online version contains supplementary material available at https://doi. org/10.1186/s13065-022-00799-w.

Additional file 1: Figures S1-S20. 2D Structure image and 1H-NMR, 13C-NMR, FT-IR spectra of compounds CHP1, CHP2, CHP3, CHP4 and CHP5. Figures S21-S23. Original photos of western bot of CHP4. Tables S1-S5. Optimized geometric properties of CHP1 to CHP5. Tables S6-S7. Vina docking results. Figures S24-S28. Diagram of the capability of the synthesized compounds in passing from BBB. Figures S29-S30. Protein and ligand interaction, ribbon model of the dimeric structure (S29), and binding pocket (S30) of AChE.

\section{Acknowledgements}

The authors thank the Research Council of the Iranian National Science Foundation (INSF) and University of Guilan for the financial support to this study.

\section{Authors' contributions}

All authors contributed to data analysis, drafting or revising the article, gave final approval of the version to be published, and agree to be accountable for all aspects of the work. MT, SA and HN carried out the experiments. MT and VAM developed the theory and performed the computations. HG, NM \& NM verified the analytical methods. AM helped supervise the project, HG supervised the project. All authors discussed the results and contributed to the final manuscript. All authors read and approved the final manuscript. 


\section{Funding}

This work is supported by the Iranian National Science Foundation (INSF, Grant No. 99027281) and the University of Guilan.

\section{Availability of data and materials}

The datasets generated and/or analysed during the current study available from the corresponding author on reasonable request. We have presented all our principal data in the form of tables, figures and supplementary.

\section{Declarations}

Ethics approval and consent to participate

Not applicable.

\section{Consent for publication}

Not applicable.

\section{Competing interests}

The authors declare that they have no known competing financial interests or personal relationships that could have appeared to influence the work reported in this paper.

\section{Author details}

'Department of Biology, Faculty of Basic Sciences, University of Guilan, Rasht, Iran. ${ }^{2}$ Department of Marine Sciences, The Caspian Sea Basin Research Center, University of Guilan, Rasht, Iran. ${ }^{3}$ Department of Chemistry, Faculty of Sciences, University of Guilan, Rasht, Iran.

Received: 12 August 2021 Accepted: 14 February 2022 Published online: 22 February 2022

\section{References}

1. Boniolo G. Demented patients and the quandaries of identity: setting the problem, advancing a proposal. Hist Philos Life Sci. 2021;43(1):1-16.

2. Mohebali N, Shahzadeh Fazeli SA, Ghafoori H, Farahmand Z, MohammadKhani E, Vakhshiteh F, et al. Effect of flavonoids rich extract of Capparis spinosa on inflammatory involved genes in amyloid-beta peptide injected rat model of Alzheimer's disease. Nutr Neurosci. 2018;21(2):143-50.

3. Moya-Alvarado G, Gershoni-Emek N, Perlson E, Bronfman FC. Neurodegeneration and Alzheimer's disease (AD). What can proteomics tell us about the Alzheimer's brain? Mol Cell Proteomics. 2016;15(2):409-25.

4. Campanella C, Pace A, Caruso Bavisotto C, Marzullo P, Marino Gammazza A, Buscemi S, et al. Heat shock proteins in Alzheimer's disease: role and targeting. Int J Mol Sci. 2018:19(9):2603.

5. Vahdani F, Ghafouri H, Sarikhan S, Khodarahmi R. Molecular cloning, expression, and functional characterization of 70-kDa heat shock protein, DnaK, from Bacillus halodurans. Int J Biol Macromol. 2019;137:151-9.

6. Ghafoori H, Askari M, Sarikhan S. Molecular cloning, expression and functional characterization of the 40-kDa heat shock protein, DnaJ, from Bacillus halodurans. Process Biochem. 2017;54:33-40.

7. Yang T, Hsu C, Liao W, Chuang JS. Heat shock protein 70 expression in epilepsy suggests stress rather than protection. Acta Neuropathol. 2008:115(2):219-30

8. Asea A, Kraeft S-K, Kurt-Jones EA, Stevenson MA, Chen LB, Finberg RW, et al. HSP70 stimulates cytokine production through a CD14-dependant pathway, demonstrating its dual role as a chaperone and cytokine. Nat Med. 2000;6(4):435-42.

9. Jinwal UK, Miyata Y, Koren J, Jones JR, Trotter JH, Chang L, et al. Chemical manipulation of hsp70 ATPase activity regulates tau stability. J Neurosci. 2009:29(39):12079-88.

10. Jahangirizadeh Z, Ghafouri H, Sajedi RH, Sarikhan S, Taghdir M, Sariri R. Molecular cloning, prokaryotic expression, purification, structural studies and functional implications of Heat Shock Protein 70 (Hsp70) from Rutilus frisii kutum. Int J Biol Macromol. 2018:108:798-807.

11. Niedzielska E, Smaga I, Gawlik M, Moniczewski A, Stankowicz P, Pera J, et al. Oxidative stress in neurodegenerative diseases. Mol Neurobiol. 2016;53(6):4094-125.
12. Butterfield DA, Boyd-Kimball D. Oxidative stress, amyloid- $\beta$ peptide, and altered key molecular pathways in the pathogenesis and progression of Alzheimer's disease. J Alzheimers Dis. 2018:62(3):1345-67.

13. Ferreira-Vieira TH, Guimaraes IM, Silva FR, Ribeiro FM. Alzheimer's disease: targeting the cholinergic system. Curr Neuropharmacol. 2016;14(1):101-15.

14. Anand P, Singh B, Singh N. A review on coumarins as acetylcholinesterase inhibitors for Alzheimer's disease. Bioorg Med Chem. 2012;20(3):1175-80.

15. Waymire J. Acetylcholine neurotransmission. Cellular and molecular neurobiology Neuroscience online University of Texas Medical School http:// neuroscience.uth.tmc.edu/indexhtm. 2000.

16. Colovic MB, Krstic DZ, Lazarevic-Pasti TD, Bondzic AM, Vasic VM. Acetylcholinesterase inhibitors: pharmacology and toxicology. Curr Neuropharmacol. 2013;11(3):315-35.

17. Zhou Y, Wang S, Zhang Y. Catalytic reaction mechanism of acetylcholinesterase determined by Born-Oppenheimer ab initio QM/MM molecular dynamics simulations. J Phys Chem B. 2010;114(26):8817-25.

18. Cheung J, Gary EN, Shiomi K, Rosenberry TL. Structures of human acetylcholinesterase bound to dihydrotanshinone I and territrem B show peripheral site flexibility. ACS Med Chem Lett. 2013:4(11):1091-6.

19. Hussain G, Rasul A, Anwar H, Aziz N, Razzaq A, Wei W, et al. Role of plant derived alkaloids and their mechanism in neurodegenerative disorders. Int J Biol Sci. 2018;14(3):341.

20. Shrivastava SK, Srivastava P, Upendra T, Tripathi PN, Sinha SK. Design, synthesis and evaluation of some $\mathrm{N}$-methylenebenzenamine derivatives as selective acetylcholinesterase (AChE) inhibitor and antioxidant to enhance learning and memory. Bioorg Med Chem. 2017;25(4):1471-80.

21. Rajini K, Aparna P, Sasikala C, Ramana CV. Microbial metabolism of pyrazines. Crit Rev Microbiol. 2011;37(2):99-112.

22. Hara T, Norimatsu N, Kurushima H, Kano T. Method for producing dichloropyrazine derivative. Google Patents; 2014

23. Dolezal M, Zitko J. Pyrazine derivatives: a patent review (June 2012-present). Expert Opin Ther Pat. 2015;25(1):33-47.

24. Miniyar PB, Murumkar PR, Patil PS, Barmade MA, Bothara KG. Unequivocal role of pyrazine ring in medicinally important compounds: a review. Mini Rev Med Chem. 2013:13(11):1607-25.

25. Zhu J, Yang H, Chen Y, Lin H, Li Q, Mo J, et al. Synthesis, pharmacology and molecular docking on multifunctional tacrine-ferulic acid hybrids as cholinesterase inhibitors against Alzheimer's disease. J Enzyme Inhib Med Chem. 2018;33(1):496-506.

26. Re R, Pellegrini N, Proteggente A, Pannala A, Yang M, Rice-Evans C. Antioxidant activity applying an improved ABTS radical cation decolorization assay. Free Radical Biol Med. 1999;26(9-10):1231-7.

27. Ghafoori H, Sariri R, Naghavi M. STudy of effect of extraction conditions on the biochemical composition and antioxidant activity of Artemisia absinthium by HPLC and TLC. J Liq Chromatogr Relat Technol. 2014:37(11):1558-67.

28. Jamalzadeh L, Ghafoori H, Sariri R, Rabuti H, Nasirzade J, Hasani H, et al. Cytotoxic effects of some common organic solvents on MCF-7, RAW-264.7 and human umbilical vein endothelial cells. Avicenna J Med Biochem. 2016:4(1):10-33453.

29. Zor T, Selinger Z. Linearization of the Bradford protein assay increases its sensitivity: theoretical and experimental studies. Anal Biochem. 1996;236(2):302-8.

30. Frisch MJ, Trucks GW, Schlegel HB, Scuseria GE, Robb MA, Cheeseman JR, et al. Gaussian 16 Rev. C.01. Wallingford, CT2016.

31. Liu H, Wang L, Lv M, Pei R, Li P, Pei Z, et al. AlzPlatform: an Alzheimer's disease domain-specific chemogenomics knowledgebase for polypharmacology and target identification research. J Chem Inf Model. 2014;54(4):1050-60.

32. Yap CW. PaDEL-descriptor: an open source software to calculate molecular descriptors and fingerprints. J Comput Chem. 2011:32(7):1466-74.

33. Trott O, Olson AJ. AutoDock Vina: improving the speed and accuracy of docking with a new scoring function, efficient optimization, and multithreading. J Comput Chem. 2010;31(2):455-61.

34. Abagyan R, Totrov M, Kuznetsov D. ICM-a new method for protein modeling and design: applications to docking and structure prediction from the distorted native conformation. J Comput Chem. 1994;15(5):488-506.

35. Ashkenazy H, Abadi S, Martz E, Chay O, Mayrose I, Pupko T, et al. ConSurf 2016: an improved methodology to estimate and visualize 
evolutionary conservation in macromolecules. Nucleic Acids Res. 2016;44(W1):W344-50.

36. Cicognola C, Brinkmalm G, Wahlgren J, Portelius E, Gobom J, Cullen NC, et al. Novel tau fragments in cerebrospinal fluid: relation to tangle pathology and cognitive decline in Alzheimer's disease. Acta Neuropathol. 2019;137(2):279-96.

37. Akbary Moghaddam V, Kasmaeifar V, Mahmoodi Z, Ghafouri H, Saberi $\mathrm{O}$, Mohammadi A. A novel sulfamethoxazole derivative as an inhibitory agent against HSP70: a combination of computational with in vitro studies. Int J Biol Macromol. 2021;189:194-205.

38. Lipinski CA. Lead-and drug-like compounds: the rule-of-five revolution. Drug Discov Today Technol. 2004; 1(4):337-41.

39. Pettersen EF, Goddard TD, Huang CC, Couch GS, Greenblatt DM, Meng EC, et al. UCSF Chimera - a visualization system for exploratory research and analysis. J Comput Chem. 2004;25(13):1605-12.

40. Wallace AC, Laskowski RA, Thornton JM. LIGPLOT: a program to generate schematic diagrams of protein-ligand interactions. Protein Eng Des Sel. 1995;8(2):127-34.

41. Mamedova G, Mahmudova A, Mamedov S, Erden Y, Taslimi P, Tüzün $B$, et al. Novel tribenzylaminobenzolsulphonylimine based on their pyrazine and pyridazines: synthesis, characterization, antidiabetic, anticancer, anticholinergic, and molecular docking studies. Bioorg Chem. 2019;93:103313.

42. Hameed A, Zehra ST, Shah SJ, Khan KM, Alharthy RD, Furtmann N, et al. Syntheses, cholinesterases inhibition, and molecular docking studies of Pyrido [2, 3-b] pyrazine derivatives. Chem Biol Drug Des. 2015;86(5):1115-20.

43. Zhu B, Zhang T, Jiang Q, Li Y, Fu Y, Dai J, et al. Synthesis and evaluation of pyrazine and quinoxaline fluorophores for in vivo detection of cerebral tau tangles in Alzheimer's models. Chem Commun. 2018;54(82):11558-61.

44. Talesa VN. Acetylcholinesterase in Alzheimer's disease. Mech Ageing Dev. 2001;122(16):1961-9.

45. Yurttaş L, Kaplancıklı ZA, Özkay Y. Design, synthesis and evaluation of new thiazole-piperazines as acetylcholinesterase inhibitors. J Enzyme Inhib Med Chem. 2013;28(5):1040-7.

46. Uysal S, Parlar S, Tarikogullari AH, Aydin Kose F, Alptuzun V, Soyer Z. Synthesis, biological evaluation, and docking studies of some 5-chloro-2 (3H)-benzoxazolone Mannich bases derivatives as cholinesterase inhibitors. Arch Pharm. 2018;351(3-4):1700273.

47. Remya C, Dileep K, Tintu I, Variyar E, Sadasivan C. Design of potent inhibitors of acetylcholinesterase using morin as the starting compound. Front Life Sci. 2012;6(3-4):107-17.

48. Feng $Y$, Wang $X$. Antioxidant therapies for Alzheimer's disease. Oxid Med Cell Longev. 2012;2012:472932.

49. Rehakova Z, Koleckar V, Jahodar L, Opletal L, Macakova K, Cahlikova L, et al. Evaluation of the antioxidant activity of several naturally occurring coumarins and their synthesized analogues by "ferric reducing antioxidant power" assay. J Enzyme Inhib Med Chem. 2014;29(1):49-54.

50. Li D-D, Zhang W, Wang Z-Y, Zhao P. Serum copper, Zinc, and iron levels in patients with Alzheimer's disease: a meta-analysis of case-control studies. Front Aging Neurosci. 2017;9:300.

51. Nikseresht S, Bush Al, Ayton S. Treating Alzheimer's disease by targeting iron. Br J Pharmacol. 2019;176(18):3622-35.

52. Vaz FNC, Fermino BL, Haskel MVL, Wouk J, de Freitas GBL, Fabbri R, et al. The relationship between copper, iron, and selenium levels and Alzheimer disease. Biol Trace Elem Res. 2018;181(2):185-91.

53. Pirali M, Taheri M, Zarei S, Majidi M, Ghafouri H. Artesunate, as a HSP70 ATPase activity inhibitor, induces apoptosis in breast cancer cells. Int J Biol Macromol. 2020;164:3369-75.

54. Evgen'ev MB, Krasnov GS, Nesterova IV, Garbuz DG, Karpov VL, Morozov $\mathrm{AV}$, et al. Molecular mechanisms underlying neuroprotective effect of intranasal administration of human $\mathrm{Hsp} 70$ in mouse model of Alzheimer's disease. J Alzheimer's Dis. 2017;59(4):1415-26.

55. Thompson AD, Scaglione KM, Prensner J, Gillies AT, Chinnaiyan A, Paulson $\mathrm{HL}$, et al. Analysis of the tau-associated proteome reveals that exchange of Hsp70 for Hsp90 is involved in tau degradation. ACS Chem Biol. 2012;7(10):1677-86.

56. Miyata Y, Koren J, Kiray J, Dickey CA, Gestwicki JE. Molecular chaperones and regulation of tau quality control: strategies for drug discovery in tauopathies. Future Med Chem. 2011;3(12):1523-37.
57. Lu R-C, Tan M-S, Wang H, Xie A-M, Yu J-T, Tan L. Heat shock protein 70 in Alzheimer's disease. BioMed Res Int. 2014;2014:435203.

58. Miyata Y, Li X, Lee H-F, Jinwal UK, Srinivasan SR, Seguin SP, et al. Synthesis and initial evaluation of YM-08, a blood-brain barrier permeable derivative of the heat shock protein 70 (Hsp70) inhibitor MKT-077, which reduces tau levels. ACS Chem Neurosci. 2013;4(6):930-9.

\section{Publisher's Note}

Springer Nature remains neutral with regard to jurisdictional claims in published maps and institutional affiliations.
Ready to submit your research? Choose BMC and benefit from:

- fast, convenient online submission

- thorough peer review by experienced researchers in your field

- rapid publication on acceptance

- support for research data, including large and complex data types

- gold Open Access which fosters wider collaboration and increased citations

- maximum visibility for your research: over $100 \mathrm{M}$ website views per year

At BMC, research is always in progress.

Learn more biomedcentral.com/submissions 